Annals of Warsaw University of Life Sciences - SGGW

Land Reclamation No 39, 2008: 129-137

(Ann. Warsaw Univ. of Life Sci. - SGGW, Land Reclam. 39, 2008)

\title{
Urban flash flood in Gdańsk, 2001
}

\author{
WOJCIECH MAJEWSKI \\ Institute of Meteorology and Water Management in Warsaw
}

\begin{abstract}
Urban flash flood in Gdańsk, 2001. Floods in urban areas cause considerable economic losses and affect many people. Measures for flood mitigation in urban areas are primarily of an engineering character, however, existing city infrastructure very often restricts the introduction of appropriate new constructions. The city of Gdańsk is situated at the mouth of the Vistula river, on the area, which forms Vistula delta. It is the most flood-prone agglomeration in Poland. Now there are three possible flood sources. The first is from the moraine hills, in case of intensive precipitation. This area was recently rapidly urbanized. The second source of flood is from the Gulf of Gdańsk caused by storm surges and the third is from main channel of Vistula river in case of very high discharge or ice jam.

The city of Gdańsk is situated within a complicated system of rivers and channels called Gdańsk Water Node $(\mathrm{GWN})$. It is influenced by the discharge of rivers flowing from the moraine hills in the west, and from possible storm surges in the Gulf of Gdańsk. In July 2001 a severe flash flood, arising for the first time from the moraine hills, caused by very intensive rainfall, hit Gdańsk. In the paper description of the operation of GWN, the flood cause, run and damages are presented. Description of measures, which were proposed to mitigate influence of a similar flood in the future are given. These measures were proposed on the basis of detailed field measurements, hydrologic analysis, hydraulic calculations and possible hydro-engineering developments.
\end{abstract}

Key words: flash flood, flood management, floods in Gdańsk, Vistula river, city of Gdańsk.

\section{THE CITY OF GDAŃSK}

Gdańsk is a great Polish port situated on the southern coast of the Baltic Sea in the lowland area at the mouth of the Vistula river. It is an important industrial, scientific and cultural centre with 460 thousand inhabitants and its area is $262 \mathrm{~km}^{2}$. It is the capital of the Pomeranian province. Therefore any flood in Gdańsk results in considerable damages.

Gdańsk and its surroundings are situated in the area known as Gdańsk Żuławy, part of Vistula delta. This region was in the past and is at present endangered by various types of flooding. In the XIXth century and earlier, the main danger of flooding was from the Gdańsk Vistula, which was the western arm of Vistula (Jasińska, Majewski 2004). The turning point in the flood problems in the Gdańsk region was the construction of a new outlet of the Vistula river to the sea in 1895, called the Przekop Wisły. The river arm, Gdańsk Vistula was cut off at Przegalina by means of a navigation lock, and thus the Dead Vistula was created (Jasińska 2002). Now the Gdańsk region has a very complicated system of rivers and channels, which constitute Gdańsk Water Node (GWN). 


\section{GDAŃSK WATER NODE}

Gdańsk region has a very complicated system of rivers and channels (Fig. 1), which constitute, so called, Gdańsk Water Node (GWN). The main river channels are Vistula and Dead Vistula. The terrains close to these rivers are protected by flood dykes. Dead Vistula has several tributaries and channels. These tributaries have at the discharge point storm gates. To prevent the inflow of salty waters into rivers and streams storm gates close automatically when water level in the Dead Vistula is higher than in the tributaries. Dead Vistula has two direct connections with the Gulf of Gdańsk, where water levels are changing due to winds and differences in air pressure. These connections were formed during floods in 1829 and 1840 . Baltic Sea is practically tideless.
There are two smaller but also very important rivers in GWN: Motława and Radunia. Motława river flows along Gdańsk Żuławy and discharges into Dead Vistula forming several branches within the city. One of them is Oplyw Motławy, which was a defensive moat of Gdańsk in ancient times. Now it forms recreation area, and to some extent is a flood retention reservoir. Radunia river flows towards Gdańsk from the moraine hills. In XXth century six small hydraulic power-plants were constructed along the river which are still in operation.

In the XIVth century an artificial channel, called Radunia Channel (RCh), was constructed. It branches from the Radunia river in the vicinity of Pruszcz Gdański. The aim of the channel was to supply water to the city of Gdańsk. It runs at the foot of moraine hills. The

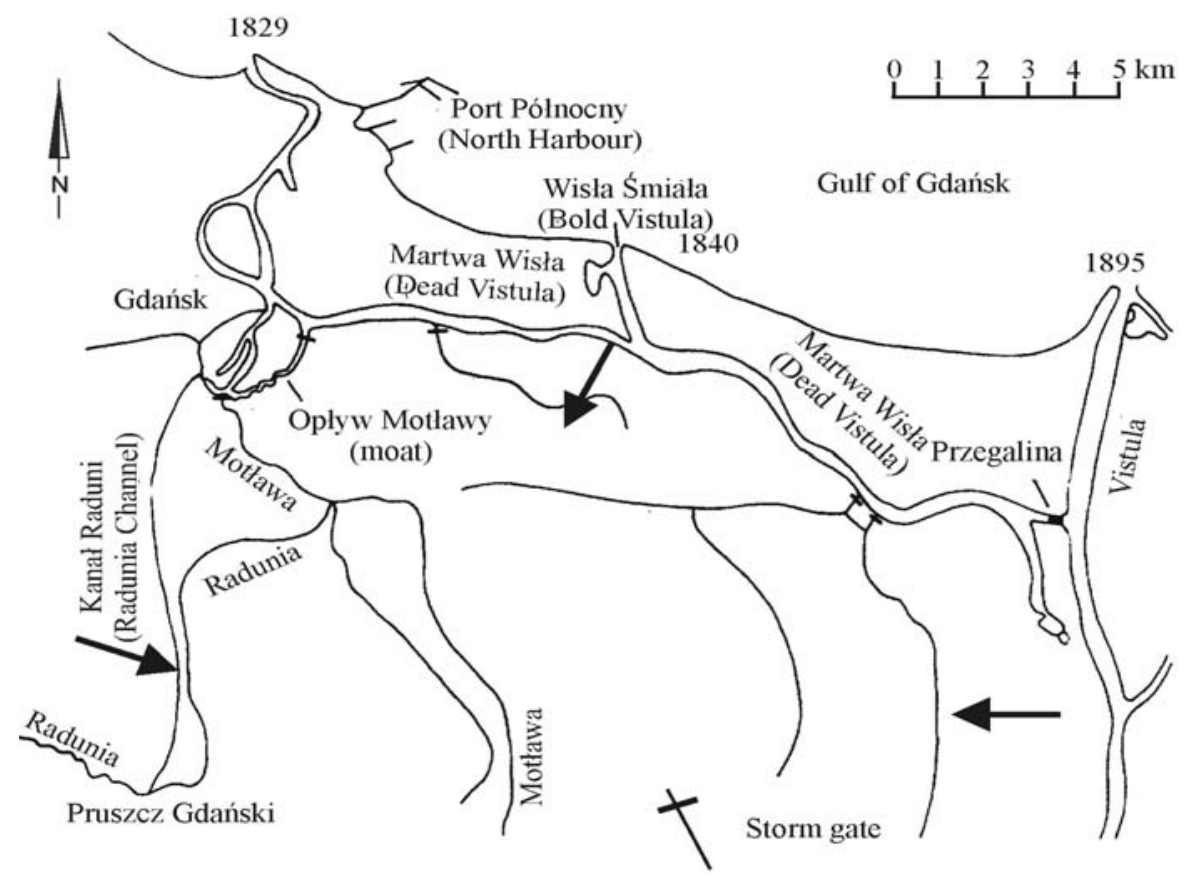

FIGURE 1. Gdańsk Water Node 
length of the Radunia Channel is $13.5 \mathrm{~km}$ and its catchment covering $55 \mathrm{~km}^{2}$. There are several small streams and outlets from storm drainage networks, which discharge into RCh. Their discharges in normal conditions do not exceed $1 \mathrm{~m}^{3} / \mathrm{s}$. The Radunia Channel plays also the role of an artificial storage reservoir for water coming from the left catchment area. The total volume of the Radunia Channel is estimated as about $0.3 \mathrm{mln} \mathrm{m}^{3}$. The bottom width of the channel is around $8 \mathrm{~m}$ and has an almost rectangular cross-section. The average slope of the channel is $0.5 \%$, its conveyance at maximum depth of $2.7 \mathrm{~m}$ was estimated at about $20 \mathrm{~m}^{3} / \mathrm{s}$. The $\mathrm{RCh}$ has an artificial outlet to the Motława river, which is the tributary of the Dead Vistula in Gdańsk. The RCh has an embankment on the right-hand side, which runs parallel to the main road leading to Gdańsk from the south. This embankment has the crest width from 3 to $5 \mathrm{~m}$ and height of 4 to $5 \mathrm{~m}$. The inner slope of the channel is in many places protected by means of concrete slabs supported on sheet piles. The area along the right bank of the $\mathrm{RCh}$ is occupied by the old urban part of Gdańsk lying in a depression. Almost along half of the length of RCh Radunia river runs parallel to it.

In recent years the area situated along the left bank of Radunia Channel was rapidly urbanized which results now in large impermeable areas as parking lots, streets, and roofs. This situation causes decrease of retention capacity and rapid run-off from these terrains into $\mathrm{RCh}$ in case of precipitation. Local authorities were often informed by engineers that critical situation will develop in case of intensive precipitation, and relatively small conveyance capacity of RCh.

\section{PRECIPITATION REGIME IN GDAŃSK AREA}

Precipitation in Gdańsk is highly non-uniform in space and time. There were frequentintensiverainstorms, which often covered only a small area. The precipitation regime is described on the basis of existing measurement data. There are only three stations for measuring precipitation in Gdańsk, which are operated by the National Meteorological Service. They are unfortunately located on the city boundaries, and therefore, it is difficult to estimate the spatial distribution of the precipitation over the whole area of Gdańsk.

The average annual precipitation in Gdańsk is about $600 \mathrm{~mm}$ and, the July average is $68 \mathrm{~mm}$. In recent decades, it was observed that the maximum daily precipitation for a particular year occurred in July. Before 2001, the maximum daily precipitation was recorded in July 1980 and amounted to $80 \mathrm{~mm}$. On the 9 July over a period of 4 hours practically the whole catchment area of the $\mathrm{RCh}$ received $80 \mathrm{~mm}$ of precipitation. The daily amount of precipitation in Gdańsk on 9 July 2001 was $120 \mathrm{~mm}$ (Fig. 2). This value was estimated to have a probability of 0.5 to $0.3 \%$ (once in 200-300 years).

\section{FLOOD RUN AND ITS CONSEQUENCES}

The flood, which occurred in Gdańsk in July 2001 was a typical urban flash flood, which came from the moraine hills, and was caused by intensive rainfall. It was the first serious flood in the Gdańsk region since the construction of the Wisła Przekop (Vistula River Direct Channel) 


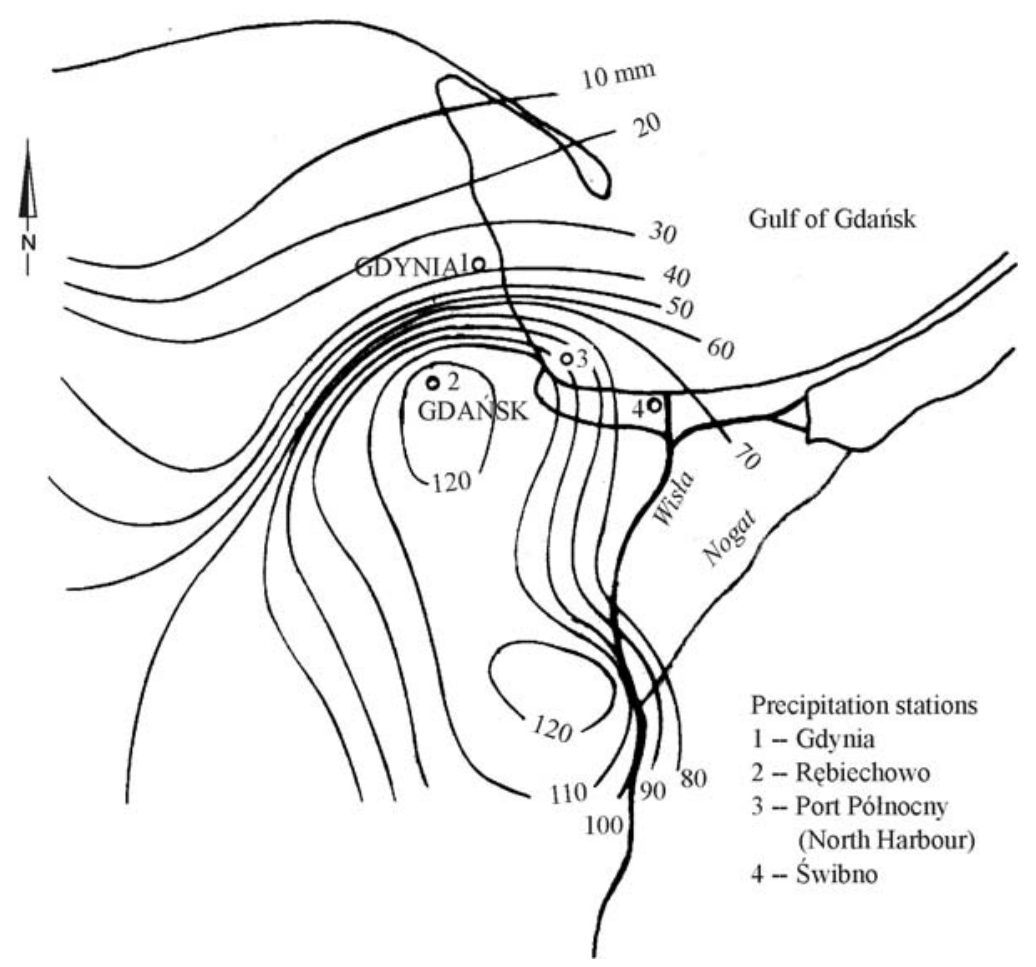

FIGURE 2. Precipitation regime in Gdańsk on 9 July, 2001

in 1895. This situation was caused entirely by very heavy rainfall just in the centre of the city. Dramatic situation was caused by the fact that flooding started within a very short time from the beginning of rainfall and the city infrastructure prevented the possibility to apply any protection measures (Majewski 2002).

As the result of intensive precipitation high inflow of water to the Radunia Channel took place. Simplified calculations showed that the inflow to the channel from the left hand catchment was about $100 \mathrm{~m}^{3} / \mathrm{s}$ over 4 hours in comparison to the channel conveyance $20 \mathrm{~m}^{3} / \mathrm{s}$. As the result of this inflow the following structures were destroyed or inundated:

- the embankment of the Radunia Channel was breached in 5 places, which resulted in flooding of the area of the city situated in the depression on the right side of the channel and the main road (Fig. 3),

- two main roads approaching Gdańsk from the west turned into torrential rivers,

- Gdańsk main railway station was flooded, which caused one week's break in traffic,

- the main embankment of the small reservoir on the Strzyża Stream in Gdańsk was breached, which resulted in a severe flood along the main street and flooding of the crossing on the road between Gdańsk and Gdynia,

- one day later the left dyke of Kłodawa river, situated about $10 \mathrm{~km}$ south form Radunia Channel was breached which 


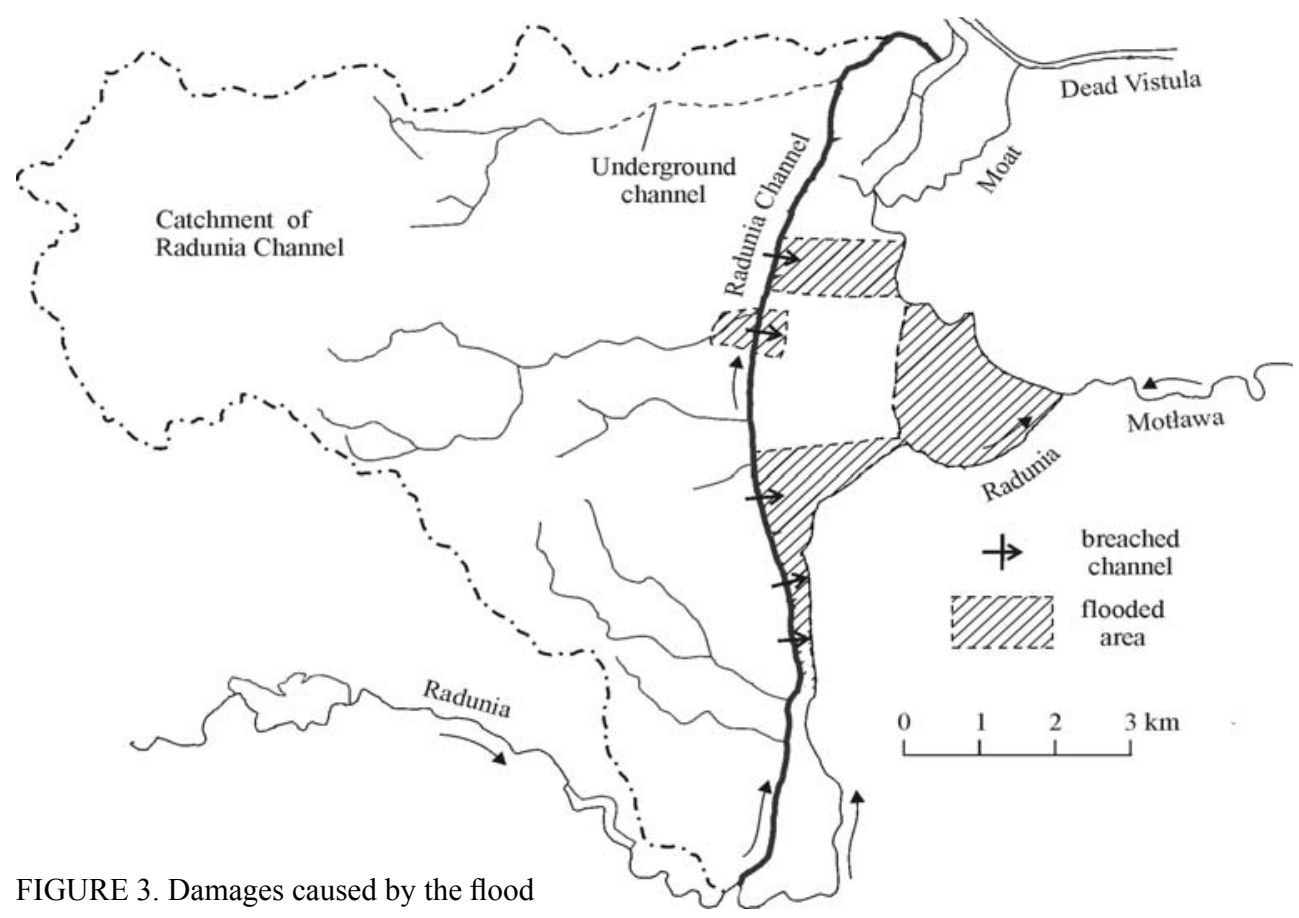

resulted in inundation of large area of agricultural land.

Losses in the city infrastructure caused by flood were very high and estimated at about $50 \mathrm{mln}$. USD. More than 300 families were affected by the flood (damaged houses, loss of property). It was necessary to rescue people and their property from complete damage and destruction. Basements of numerous houses were flooded and required draining and drying. About 5000 people received special calamity status, which affords social assistance.

The embankment of the RCh was quickly repaired to prevent further flooding of low lying areas. Simultaneously, pumping was carried out to drain the flooded areas. A difficult and slowly proceeding action was to repair of the streets and remove sediments carried in by the flowing water.

\section{FLOOD PROTECTION PROJECT}

After the flood of 2001, the local authorities (Regional Board of Water Management in Gdańsk) decided that it was necessary to undertake steps to improve flood protection in the Gdańsk area in future, especially in the region of RCh (Majewski et al. 2003, 2004). The analysis of the existing spatial situation of the city indicates, however, that the present infrastructure does not allow any mayor change in the network of channels in the Gdańsk area. In order to solve this problem a special consortium was called into being, which consisted of four institutions, including research institutes and design and consulting firms. The main tasks were defined as follows:

- measurements of all rivers and channels forming Gdańsk Water Node (cross-sections and longitudinal profiles), 
- hydrologic analysis of rivers and streams together with water level changes in the sea,

- development of 1D unsteady flow model of the whole system of rivers and channels including all bridges and hydraulic structures,

- calculations for various possible variants of flood protection,

- analysis of results and proposal of technical solutions.

Detailed information of all rivers, streams and channels were necessary for the formulation of the numerical model. It was decided to validate all existing cross-sections as some of them were measured several years ago. More than 250 cross-sections of river channels were measured. In these cross-sections hydraulic structures, bridges and flood dykes were recorded. Actual water levels were also measured. All the data were recorded in one unified geodetic system. Several data from previous measurements were compared and corrected. All these data formed the basis for the numerical model. Special attention was given to the height of flood dyke crests. It was found in numerous places that local lowering of the dyke crest could be the reason for dyke overtopping and subsequent breaching.

One of the main tasks of the project was the collection and analysis of hydrologic data. These concerned discharges and water levels in all rivers and streams of the GWN. It was also necessary to determine the probabilities of extreme discharges, which could appear in the rivers Radunia and Motława. Simultaneously, changes of water levels with time in the Gulf of Gdańsk were also analyzed. Possible coincidence of high water levels in the Gulf of Gdańsk, and thus in Dead Vistula, together with high discharges in the rivers of GWN were analyzed. These data were taken into account for subsequent hydraulic calculations. An important task was also the determination of roughness coefficient of various channels to include in the mathematical model.

The 1D model was developed on the basis of MIKE 11 (DHI Water and Environment). The upstream boundary condition was the discharge in Radunia and Motlawa rivers. The downstream boundary condition is constituted by water level in the Dead Vistula. In case of water level rise in the Gulf of Gdańsk the storm gates close automatically and the downstream sections of the Motława and the Motława moat are being filled with water.

A special part of the model was the RCh catchment. This was divided into subcatchments of the streams and areas between them. Inflows to the Radunia Channel were determined by means of empirical formulas and the possibility of conveying this discharge downstream was calculated. In the majority of extreme situations it appeared that the conveyance of the channel might be too small and controlled side outflows from the channel are necessary. All these situations have to be included in the model.

\section{PROPOSED SOLUTIONS FOR FLOOD MITIGATION}

When the 1D mathematical model was verified, several calculations were performed. The first calculation concerned the determination of maximum discharge, which could be conveyed through the 
system of rivers and channels without flooding the protected area. The second series of calculations was for the design discharge of $1 \%$ probability estimated from hydrologic analysis. These calculations had to indicate in which places existing flood dykes are too low and need heightening. Calculations indicated also the need of increased retention in the catchment of the channel in the form of small retention reservoirs, as well as additional outflows from the $\mathrm{RCh}$ to the Motława and Radunia rivers, as the conveyance of the channel could not be increased beyond $20 \mathrm{~m}^{3} / \mathrm{s}$, because RCh is a historical construction, and because there are numerous ecological organizations which are against substantial changes in the channel. Sample calculation of discharge changes in the Radunia river and water elevations along its run are shown in Figure 4. Hydraulic calculations indicated also that in some places only small rise in the dyke crests is necessary to increase conveyance of flood waters.

On the basis of the hydraulic calculations and analysis of all the circumstances, it was decided to construct 18 small artificial storage reservoirs on all the streams discharging into the Radunia Channel, in order to decrease the inflow in case of intensive precipitation. This will retain water in the channel catchment temporarily. Their total volume is $420 \cdot 10^{3} \mathrm{~m}^{3}$ and this is not sufficient to accommodate all water from intensive rainfall. Therefore, it was proposed also to construct 3 additional control outflows from the $\mathrm{RCh}$ to the Radunia and Motlawa rivers to diminish the flow in

Water level (m)

Discharge $\left(\mathrm{m}^{3} / \mathrm{s}\right)$

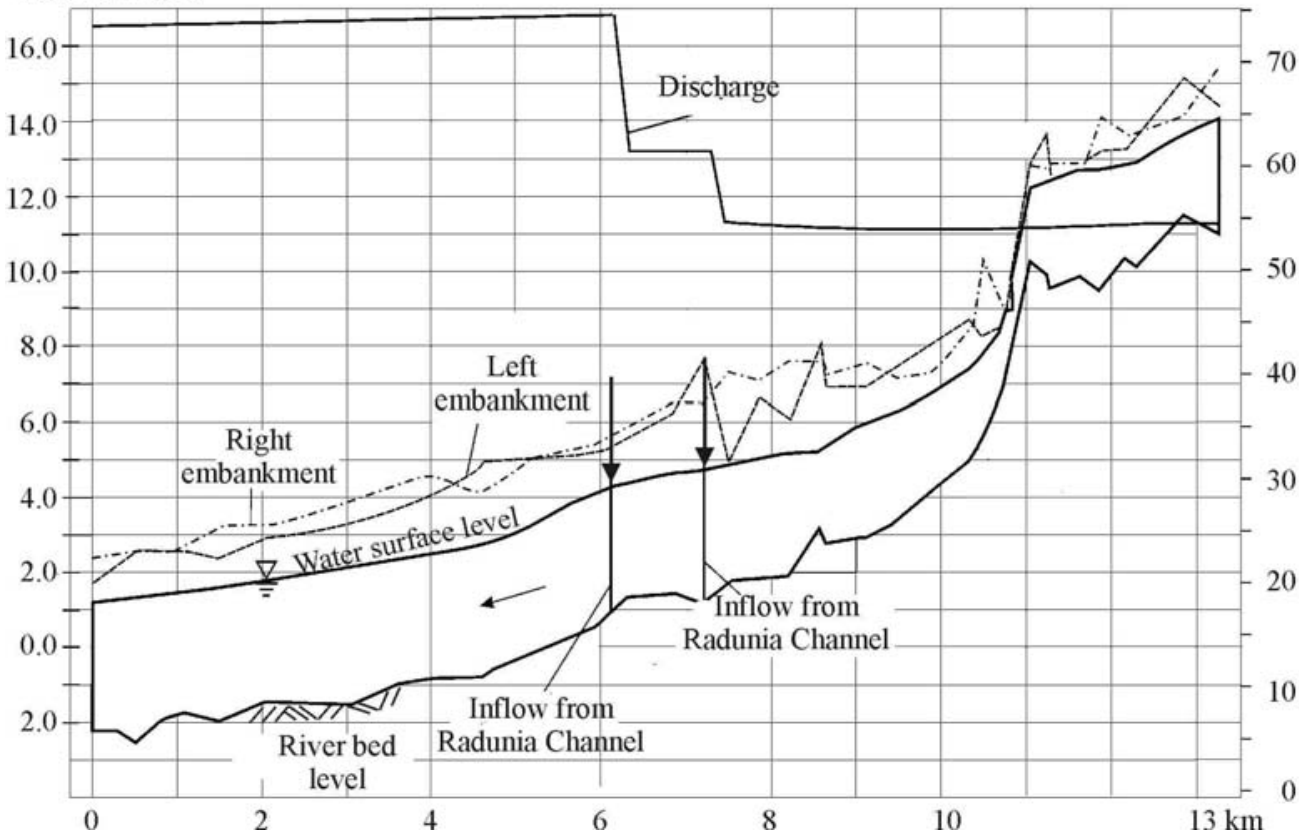

FIGURE 4. Results of calculations, water levels along Radunia river 
the channel in case of high precipitation. Two flood polders are also planned (Fig. 5), which can be operated in case of an extremely strong storm surge and simultaneous high water level in the Motława river.

\section{CONCLUSIONS}

Flood in Gdańsk in 2001 clearly indicated that the city is not prepared to face intensive precipitation, and new solutions to mitigate such situation are necessary. The existing spatial situation of the city of Gdańsk indicates the difficulty in carrying out of any general change in the network of channels in the Gdańsk area. The $\mathrm{RCh}$ is of great importance for possible floods caused by intensive precipitation in the city of Gdańsk. It was found that there is no possibility of significantly increasing the conveyance of the RCh. Moreover, it is a monument of technology and change of its construction or layout requires acceptance from the Gdańsk Architect's Office.

In order to decrease the inflow to the $\mathrm{RCh}$ in case of intensive precipitation it was decided, on the basis of hydraulic calculations, to construct 18 small reservoirs on all streams discharging to the RCh and install 3 additional control outflows from the channel to the Radunia and Motława rivers. In addition, 2 flood polders were proposed for extreme situations. The proposed constructions

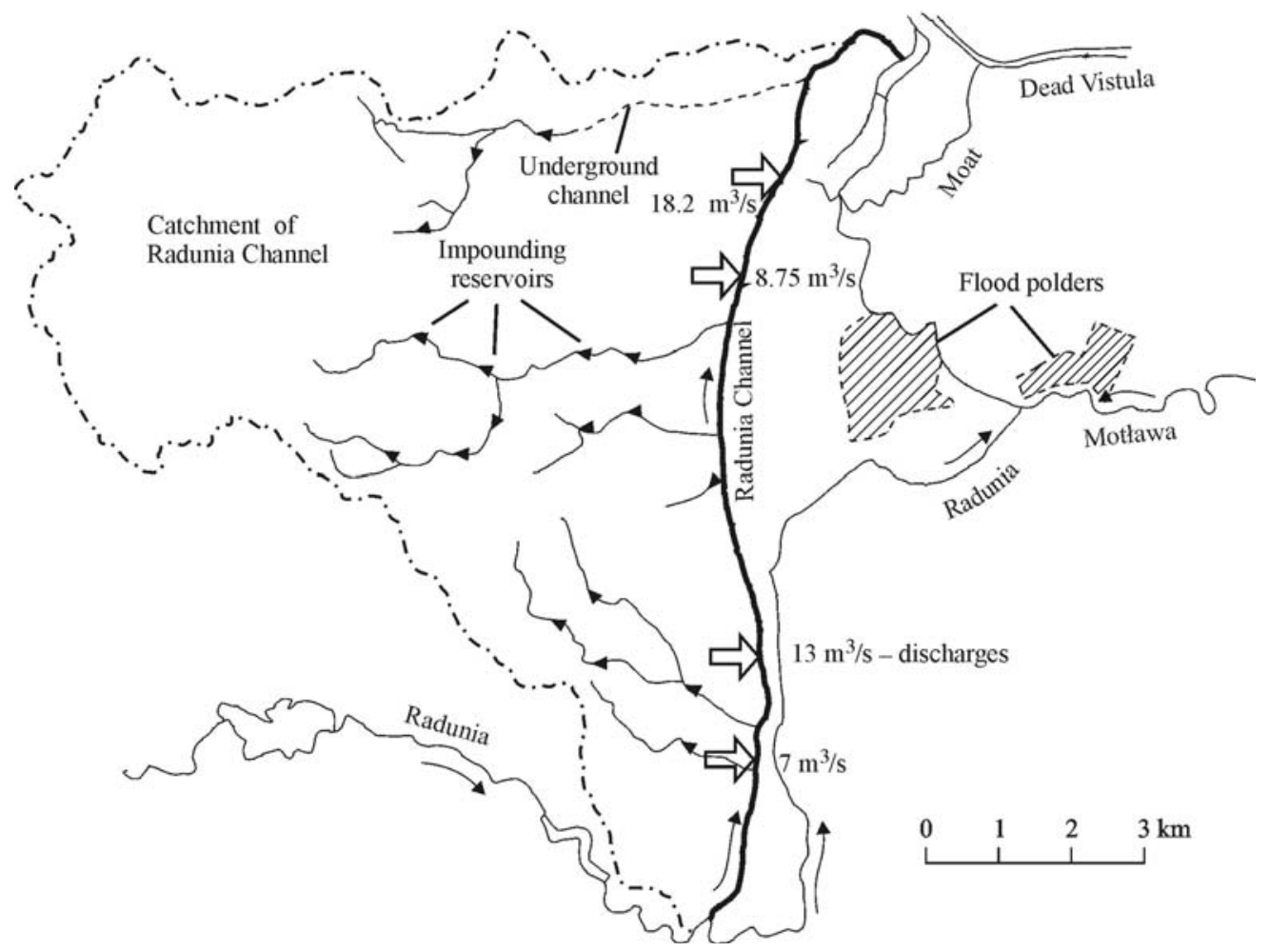

FIGURE 5. Proposed solutions for flood mitigation 
are expensive and it will take several years to put them into operation.

The storm gates Brama Żuławska and Kamienna Grodza play a very important role in the Gdańsk Water Node. Depending on water levels in Martwa Vistula caused by storm surges and the inflow to Motława moat, two situations are possible. Closure of the gates and impoundment of Motława moat and Motława river upstream. In the second case storm surge does not result in closing of the storm gates, but only increased water levels in Motława moat. In this case the discharge is through both storm gates and its intensity depends on the difference in water elevation on both sides of them.

It is also proposed to install automatic precipitation and water level gauges net in the GWN to create, together with meteorological radar, a flood warning system.

One social conclusion is of great importance. People and local authorities quickly forget about the flood and disaster caused by the inundation.

\section{REFERENCES}

JASIŃSKA E. 2002: Hydrology and hydrodynamics of Martwa Vistula and Vistula Przekop (in Polish), Publication of the Institute of HydroEngineering.

JASIŃSKA E., MAJEWSKI W. 2004: Flood problems in the city of Gdańsk, Proceedings Defra Flood and Coastal Management Conference.

MAJEWSKI W. 2002: Flood in Gdańsk in July 2001, Proceedings Conference Integrated Disaster Risk Management, IIASA Laxemburg, Austria.

MAJEWSKI W. et al. 2003, 2004: The model of water distribution in the Gdańsk Water Node for flood protection in the Martwa Vistula catchment, Institute of Hydro-Engineering Gdańs, (unpublished internal report, in Polish).

MIKE 11, Hydrodynamic Module, DHI Water and Environment.

Streszczenie: Miejska powódź błyskawiczna w Gdańsku w 2001 roku. Powodzie na obszarach miejskich powodują ogromne straty ekonomiczne, a także nieraz śmierć ludzi. Działania podejmowane dla ograniczenia skutków powodzi na obszarach miejskich mają charakter zabiegów inżynierskich, jednak istniejąca infrastruktura ogranicza wprowadzenie właściwych nowych konstrukcji. Miasto Gdańsk usytuowane jest u ujścia Wisły, na terenie, który tworzy deltę Wisły. Jest to najbardziej zagrożona powodziami aglomeracja w Polsce. Istnieją trzy potencjalne obszary kształtujące przepływy powodziowe. Pierwszy obejmuje wzgórza morenowe, ostatnio intensywnie urbanizowane. Drugi to Zatoka Gdańska z której nagły napływ wód spowodowany jest spiętrzeniami wiatrowymi, a trzeci to główne koryto Wisły podczas wysokiego przepływu lub zatoru lodowego. Gdańsk jest usytuowany w skomplikowanym systemie rzek i kanałów zwanego Gdańskim Węzłem Wodnym (GWW). W lipcu 2001 roku nawiedziła ten obszar groźna powódź wywołana gwałtowną ulewą. W referacie przedstawiono opis i działanie GWW, przyczynę powodzi i jej przebieg oraz spowodowane straty. Przedstawiono propozycje w celu złagodzenia podobnej powodzi w przyszłości. Podano również rozwiązania, które zostały zaproponowane na podstawie szczegółowych pomiarów w terenie, analizę hydrologiczna, obliczenia hydrauliczne i możliwe rozwiązania inżynierskie.

\section{MS. received April 2008}

Author's address:

Instytut Meteorologii i Gospodarki Wodnej

01-673 Warszawa, ul. Podleśna 61

Poland

e-mail: Wojciech_Majewski@imgw.pl

wmaj@ibwpan.gda.pl 